\title{
八面体席に欠陥を持つ単斜輝石 \\ Clinopyroxenes having vacancies in octahedral sites
}

奥井眞人・澤田晴朗・丸茂文幸 (日大文理)

M席に空孔を持つ単斜輝石は南アフリカのBersbank kimberliteなどで報 告がある。また，Wood and Henderson(1978)は25.0-32.3kbの高圧下で M席に空孔を持つ単斜輝石を合成し, 高圧では石英や化学量論比を満たす輝 石よりも, このような空孔を持つ化学量論比を満たさない単斜輝石が安定で あると考えている。演者らは, 従来, 報告のなかった常圧の下で, M席に空 孔を持つ単斜輝石を合成したので報告する。

合成された単斜輝石の化学組成を EPMAにより調べたところ, 酸素を6とし たときの割合として表された化学組成は Ca0.74 Mg0.01Al0.95 Fe0.03 $\square 0.25$

（Al0.51Si149）O6となった。ここではSiはすべてT席に入り，T席にはSiと合 わせて 2 にるまでAlが入るものと考えた。 M席は残った Alと他の陽イオン が占めるものとした。T席でTschermak置換をしているAlの量を超えて M席 にA 1 が存在している。M席を過剩に3 価の陽イオンが占めている結果, 電気 的中性を保つためにM席に空孔が生じるものと考えられる。

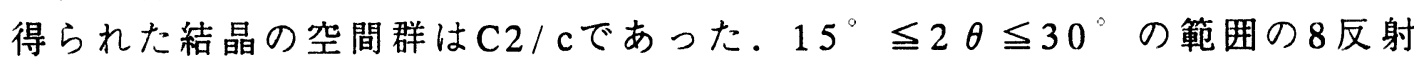
を用いて格子定数を決定したところ， $a=9.685(9) \dot{A}, b=8.794(3) \dot{A}$, $\mathrm{c}=5.295(2) \dot{A}, \beta=106.15(6)^{\circ}$ を得た。四軸型 $\mathrm{X}$ 線回折計を用いて $0^{\circ}<2$ $\theta \leqq 90^{\circ}$ の範囲で測定して得た 296 個の独立反射を用いて, 透輝石の原子バ ラメータを出発值とし, 各原子の原子座標, 等方性温度因子を最小自乗法に より精密化したところ， $\mathrm{R}=0.081 ， \mathrm{Rw}=0.103$ で収束した。精度が低いの は試料の小さいことによる。M1席およびM2席における元素の分配は, 化学 分析の值が正しいものと仮定し，CaがM2席に，A1，MgおよびF eがM1席に 存在すると仮定した。構造解析の結果から, 空孔はM2席に存在する。

表1原子座標および温度因子

\begin{tabular}{|c|c|c|c|c|c|}
\hline & 占有率 & $\mathrm{x}$ & $\mathrm{y}$ & $\mathrm{z}$ & $\mathrm{B}$ \\
\hline $\mathrm{M} 1$ & 1 & 0 & $0.9083(9)$ & $1 / 4$ & $0.39(10)$ \\
\hline $\mathrm{M} 2$ & 0.740 & 0 & $0.3070(7)$ & $1 / 4$ & $0.12(7)$ \\
\hline $\mathrm{T}$ & 1 & $0.2878(5)$ & $0.0930(7)$ & $0.2227(8)$ & $0.85(8)$ \\
\hline O1 & 1 & $0.1113(13)$ & $0.0888(16)$ & $0.1314(23)$ & $1.4(2)$ \\
\hline O2 & 1 & $0.3646(15)$ & $0.2561(16)$ & $0.3197(25)$ & $1.2(2)$ \\
\hline O3 & 1 & $0.3523(15)$ & $0.0199(15)$ & $0.9955(26)$ & $1.1(2)$ \\
\hline
\end{tabular}

参照文献 : Wood and Henderson (1978)Compositions and unite-cell parameters synthetic non-stoichiometric tschermakitic clinopyroxenes.Am.Mineral. ,63,66-72. 